\title{
Desakralisasi film horor Indonesia dalam kajian reception analysis
}

\author{
Yohana Debby $^{1}$, Theresia Intan Putri Hartiana ${ }^{2}$, Nanang Krisdinanto ${ }^{3}$ \\ 1,2,3Universitas Katolik Widya Mandala Surabaya, Indonesia
}

\begin{abstract}
ABSTRAK
Penelitian mendeskripsikan mengenai penerimaan penonton mengenai desakralisasi agama yang tergambarkan dalam film horor Indonesia pasca Orde Baru. Beberapa film yang akan diteliti diantaranya Asih (2018), Danur 2: Maddah (2018), Pengabdi Setan (2017), Ruqyah: The Exorcism (2017), Hantu Jeruk Purut Reborn (2017), dan Hantu Rumah Ampera (2009). Desakralisasi dalam film tersebut terbagi dalam tiga hal, yakni: tokoh agama, ritual, dan simbol keagamaan. Desakralisasi merupakan penurunan makna dari nilai atau hal-hal yang dianggap sakral dalam kehidupan sosial. Beberapa adegan di film horor Indonesia, menunjukkan desakralisasi, seperti tokoh agama yang kalah dengan setan, diganggu saat beribadah. Sehingga desakralisasi dikatakan sebagai suatu upaya untuk menurunkan sifat religi benda atau hal yang dianggap suci dan mengedepankan rasionalitas dalam menghadapi suatu konflik pada suatu hal. Pemilihan informan didasarkan pada usia, agama, aliran kepercayaan, pendidikan. Penelitian ini dilakukan metode analisis resepsi, teknik wawancara mendalam, serta menggolongkan hasil penerimaan informan ke dalam tiga kategori posisi yang dikemukakan oleh Stuart Hall, yakni: dominan, negosiasi, oposisi. Hasil penelitian menunjukkan bahwa informan memiliki posisi yang berbeda-beda dalam memaknai film horor. Penonton atau informan berada pada oposisi ketika memaknai desakralisasi ritual keagamaan. Informan cenderung pada oposisi karena dipengaruhi pengalaman dan latar belakang seperti pernah melewati ritual pembukaan mata batin dan melakukan ibadah.
\end{abstract}

Kata-kata Kunci: Penelitian khalayak; desakralisasi; horor Indonesia; tokoh agama; simbol agama

\section{Desacralization of Indonesian horror films in the reception analysis study}

\begin{abstract}
The study describes audience reception regarding the desacralization of religion depicted in Indonesian horror films after the New Order. Some films that will be investigated include Asih (2018), Danur 2: Maddah (2018), Pengabdi Setan (2017), Ruqyah: The Exorcism (2017), Hantu Jeruk Purut Reborn (2017), and Hantu Rumah Ampera (2009). Desacralization in the film is divided into three things, namely: religious leaders, rituals, and religious symbols. Desacralization is a decrease in the meaning of values or things that are considered sacred in social life. Some scenes in Indonesian horror films, show desacralization, such as religious leaders who are inferior to demons, are disturbed during worship. So that desacralization is said to be an attempt to reduce the religious nature of objects or things that are considered sacred and promote rationality in dealing with a conflict in a matter. The choice of informants is based on age, religion, belief, education. This research is conducted by reception analysis method, in-depth interview techniques, and classification on the results of the informant's reception into three categories of positions proposed by Stuart Hall, namely: dominant, negotiated, opposition. The results showed that the informants had different positions in interpreting horror films. The audience or informant is an opposition when interpreting the desecralization of religious rituals. Informants tend to be an opposition because they are influenced by experience and background such as had gone through the ritual of opening the inner eye and worship.
\end{abstract}

Keywords: Audience research; desacralization; Indonesian horror; religious leaders; religious symbols

Korespondensi: Yohana Debby, S.I.Kom. Fakultas Ilmu Komunikasi, Universitas Katolik Widya Mandala Surabaya, J1 Dinoyo No. 42-44, Surabaya, Jawa Timur, 60265.Email: ydebbyadelia@gmail.com 


\section{PENDAHULUAN}

Seiring dengan perkembangan tren, genre, dan teknologi film dunia, film nasional juga semakin bervariasi, salah satu genre yang berkembang yaitu horor (Sukatno \& Bazaleel, 2014). Komentator budaya Indonesia telah mencoba menjelaskan bahwa daya tarik film-film horor itu terkait erat dengan jiwa orang Indonesia dan umumnya melekat pada budaya Timur yang dianggap identik dengan mistisisme dan kejadian makhluk supernatural dan peristiwa-peristiwa mistik (Heeren, 2012). Sejak tahun 1934 film horor mulai dikenal di Indonesia pada pemerintahan Hindia Belanda berawal dari munculnya poster berjudul Ouw Peh Tjoa. Poster tersebut merupakan poster film horor pertama yang bertemakan tentang makhluk siluman jadi-jadian (Lutfi 2013).

Film horor pertama dalam sinema Indonesia diproduksi pada tahun 1934 oleh The Teng Cun dan berjudul: Two Snake Siluman Black and White (Doea Siloeman Oeler Poeti en Item). Sejak film itulah film-film horor Indonesia muncul di bioskop, bioskop keliling, dan di televisi dalam jumlah yang bervariasi. Kemudian sejak adanya film Ratu Ular (1972), jumlah film horor yang diputar di bioskop Indonesia meningkat. Film horor adalah satusatunya jenis film yang masih diproduksi setelah tahun 1993, ketika bioskop Indonesia runtuh (Heeren, 2012).

Heider menyatakan bahwa film horor Indonesia pada masa Orde Baru tidak bisa dilepaskan dari tiga hal, yaitu komedi, seks, dan religi (Herawati, 2011). Ketiganya menjadi hal yang ampuh untuk membuat film horor Indonesia digemari penontonnya. Selain kekuatan supernatural dan komedi dalam film horor Indonesia, terdapat juga 2 ciri khas film horor Indonesia lainnya yaitu penggunaan simbol agama dan tokoh agama sebagai protagonis (Heeren, 2007).

Heeren mengatakan bahwa film-film horor Indonesia sudah mulai menggunakan simbolsimbol agama pada 1970-an dan banyak kyai muncul dalam film-film horor dari tahun 1978 dan seterusnya. Suyono dan Arjanto mengatakan bahwa fitur klasik kedua dari film horor ialah penggunaan simbol agama dan deus ex machina dalam bentuk pemimpin agama, seorang kyai (guru agama Islam), pendeta, atau pendeta Hindu untuk mengatasi semua kejahatan di akhir film (Heeren, 2007). Hal itu menjadi elemen khas pada tahun 1980-an. Kyai, ulama (guru atau pemimpin agama Muslim), atau tokoh-tokoh agama lain muncul dalam film-film horor.

Setiap era film horor Indonesia mengalami perubahan dalam memasukkan atau menonjolkan unsur religi ke dalam film. Pada tahun 1996 atau 1997, ada masalah 
yang dirasakan karena film-film mistis atau horor membuat orang Indonesia tersesat dari kenyataan dan zaman modern (Heeren, 2007). Selain itu bagi mereka yang berlatar belakang Islam, masalahnya bukan karena film horor tidak menampilkan kyai untuk memecahkan masalah lagi, namun orang-orang tersebut beberapa kali telah keberatan dengan anggapan penyalahgunaan ayat-ayat Al-Quran dalam film-film mistis atau horor, dan dianggap hanya sebagai mantra untuk mengusir hantu daripada diwakili sebagai kode dari sebuah keyakinan. Pada masa Orde Baru, seorang kyai dianggap sebagai tokoh utama atau ahli yang tepat untuk memulihkan ketertiban dalam film-film horor yang berurusan dengan hal-hal tabu bagi publik, sebagai cara untuk menghindari sensor (Heeren, 2012). Sementara itu, saat ini banyak peraturan sensor dan pedoman Orde Baru untuk produksi film menjadi tidak digunakan lagi selama Reformasi atau pasca Orde Baru.

Sehingga, pada setiap era dapat terlihat adanya perbedaan penggambaran agama atau sisi religius dalam film horor Indonesia. Semisalnya pemimpin agama yang kalah dengan kekuatan setan, pada saat berdoa setan tetap mengganggu, hingga saat sholat dapat kerasukan setan. Hal tersebut menjadi sebuah perbedaan bahkan perubahan dalam film horor Indonesia dari masa Orde Baru hingga pasca Orde Baru atau Reformasi saat ini. Meski sudah tidak lagi dalam masa Orde Baru tetapi tokoh, ritual, maupun simbol agama dalam film horor tetap dimunculkan namun tidak menonjol, bahkan tidak menjadi bagian yang penting atau utama seperti dahulu lagi, "kebaikan yang menang".

Fenomena seperti ini bisa saja dikatakan sebagai desakralisasi terhadap tokoh, ritual, maupun simbol agama yang seharusnya memiliki unsur sakral atau nilai sakral. Sakral merupakan suatu hal yang lebih mudah dirasakan daripada dilukiskan (Muhammad, 2013). Bilamana terdapat suatu anggapan bahwa suatu benda sakral tersebut mengandung hal yang suci, dan didalamnya mengandung misteri yang mengerikan tetapi mengagungkan. Diantara masyarakat, terdapat pandangan yang berbeda-beda mengenai mana benda yang suci atau sakral, dan benda yang biasa-biasa saja. Suatu benda dapat disucikan atau dihormati disebabkan ada perasaan batin dan perasaan yang tertanam di dalam jiwanya dan juga adanya rasa ketakutan. Perasaan kagum inilah untuk menarik masyarakat atau manusia untuk cinta dan ingin terhindar dari bahaya. Serta perlu dijelaskan pula bahwa antara benda yang suci dan yang tidak suci (Muhammad, 2013). Sedangkan desakralisasi itu sendiri menurut Svensson Lapian merupakan suatu upaya untuk menurunkan sifat religi dan mengedepankan rasionalitas dalam menghadapi suatu konflik 
(Lapian, 2017).

Penelitian ini bertujuan melihat pemaknaan mengenai desakralisasi tokoh agama menggunakan metode reception analysis untuk mendeskripsikan bagaimana audience dengan latar belakang dan pengalaman yang berbedabeda melihat adegan desakralisasi yang ada. Pemaknaan audience tersebut dikategorikan dalam 3 kategori dengan menggunakan paradigma encoding- yaitu dominan, oposisi, dan negosiasi (Hall, 2005). Sesuai dengan kriteria subjek yang peneliti pilih, peneliti ingin mendapatkan variasi jawaban dari tiap subjek penelitian yang ada. Teori reception membahas bagaimana individu-individu menerima dan menafsirkan sebuah teks yang disajikan media dan bagaimana latar belakang individu (seperti gender, agama, ras, budaya, dan sebagainya) (Imran, 2012). Maka dari itu penelitian ini akan menghasilkan beragam pemaknaan yang dilakukan oleh subjek penelitian mengenai "desakralisasi agama" dalam tiap film yang dipilih peneliti.

\section{METODE PENELITIAN}

Penelitian ini fokus pada khalayak atau penonton dalam menerima pesan yang ada dalam media. Penelitian ini menggunakan metode reception analysis. Apa yang terdapat dalam teks media dapat dengan bebas dimaknai oleh subjek penelitian yakni penonton dewasa yang menonton film Asih (2018), Danur 2: Maddah (2018), Pengabdi Setan (2017), Ruqyah: The Exorcism (2017), Hantu Jeruk Purut Reborn (2017), dan Hantu Rumah Ampera (2009). Berdasarkan latar belakang umur, pendidikan atau status pekerjaan, dan agama, narasumber yang diambil adalah orang dewasa, yang berada pada rentang umur 21-40 tahun, pendidikan pelajar hingga pekerja, dan beragama Islam maupun Katolik dan Kristen Protestan. Dalam metode ini, khalayak atau penonton bebas untuk memaknai isi film karena disini narasumber dianggap berperan aktif dalam menerima pesan dari media massa.

\section{HASIL DAN PEMBAHASAN}

Dalam penelitian ini peneliti mengambil sebanyak 5 orang informan dengan beberapa kriteria yang telah ditentukan. Kriteria-kriteria tersebut ialah, berusia sekitar 21 hingga 40 tahun, berpendidikan SMA, Strata-1 (S1) ataupun sedang berkuliah, beragama Islam (NU dan Muhammadiyah), Katolik, Kristen, etnis apapun, serta suka menonton film. Informan 1 bernama Miftahul Jannah, usia 21 tahun, beragama Islam (NU), lulusan S1 fakultas Bimbingan Konseling Islam di Universitas Islam Negeri Sunan Ampel Surabaya. Informan 2 bernama Nanda Putra Nurprimastya, usia 22 tahun, beragama Islam (Muhammadiyah), masih berkuliah semester akhir di fakultas 
Hukum, Universitas Brawijaya Malang. Informan 3 bernama Dian Indita Yunistirianti, usia 26 tahun, beragama Kristen Protestan, sedang bekerja sebagai guru SD di sekolah dasar Kristen Petra 11 Surabaya. Informan 4 bernama Topo Puro Pangestu, usia 21 tahun, berkepercayaan Kejawen, bekerja sebagai barber dan pelatih silat. Informan 5 bernama Dony Immanuel Suwu, usia 40 tahun, beragama Katolik, bekerja sebagai pegawai swasta.

Cukup banyak film horor Indonesia yang menyelipkan sisi religius seperti tokoh dan simbol agama, maka dari itu peneliti hanya mengambil beberapa film yang sesuai dengan topik penelitian. Diantaranya adalah film Asih (2018), Danur 2: Maddah (2018), Pengabdi Setan (2017), Ruqyah: The Exorcism (2017), Hantu Jeruk Purut Reborn (2017), Hantu Rumah Ampera (2009), dan Hantu Jeruk Purut (2006).

Peneliti memilih film-film horor Indonesia dikarenakan desakralisasi tokoh agama atau sisi religius dalam film-film yang menonjol. Hal-hal tersebut yang tergambarkan dalam film cukup menyimpang dari kata 'sakral' itu sendiri, jadi apa yang seharusnya sakral dan sudah dianggap sakral oleh banyak orang namun digambarkan menjadi tidak sakral lagi. Kejadian seperti itu dapat dikatakan sebagai desakralisasi. Sehingga film-film tersebut menjadi film pilihan peneliti sesuai dengan topik penelitian ini. Semua jenis perdukunan, takhayul, benda-benda mistis, setan, dan sejumlah makhluk gaib lainnya yang tampaknya tak ada habisnya dikutip sebagai bagian yang sering muncul dari kepercayaan dan budaya masyarakat Indonesia. Dari situ, peneliti ingin mengetahui bagaimana sisi audiens dalam memaknai film-film horor Indonesia pasca Orde Baru lebih mengutamakan rasionalitas atau sudah jarang lagi memasukkan unsur religi.

$$
\text { Wawancara mendalam (in-depth }
$$

interview) antara peneliti dengan informan di tempat yang cukup beragam karena harus mencari tempat yang kiranya nyaman untuk melakukan wawancara, seperti halnya di rumah atau di kafe. Sebelum memulai wawancara mendalam, peneliti meminta informan untuk menonton dahulu sebelum peneliti datang
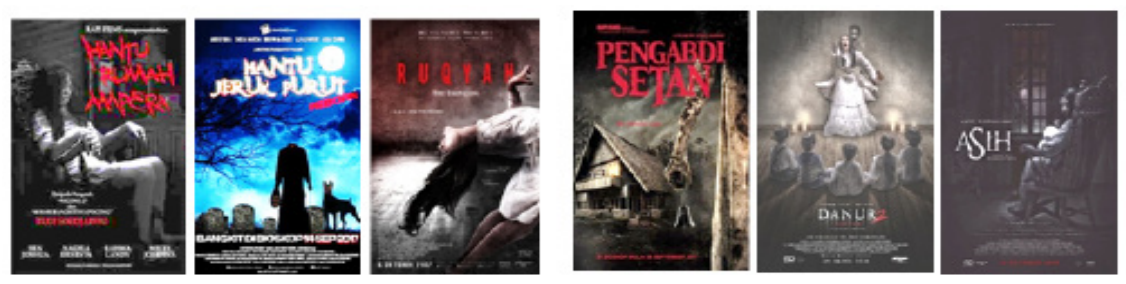

Sumber: Data penelitian, 2019

Gambar 1 Poster Film-Film Horor Indonesia Pilihan Peneliti 
untuk wawancara. Dengan begitu peneliti tentu memberikan dahulu kepada satu per satu informan file atau link dari film-film yang hendak dibahas dalam wawancara. Pemberian file dan link film dilakukan peneliti melalui personal message atau bertemu secara langsung dan memberikan lewat flashdisk. Untuk durasi wawancara berkisar antara 45 menit hingga 1 jam, dengan ketentuan jam bertemu yang telah disesuaikan dengan waktu kosong yang dimiliki tiap informan.

Dalam setiap agama itu sendiri terdapat seseorang yang dianggap suci. Kekuasaan seorang pemimpin Gereja dan juga seorang kyai dalam lingkungan pesantren, dapat dianalogikan sebagai sultan dalam tradisi istana (Hadi, 2006). Selain itu tokoh agama merupakan seseorang yang dipercayakan dalam suatu agama untuk membimbing setiap umat supaya bisa lebih mendekat kepada Tuhan. Caranya melalui ajaran-ajaran sesuai dengan kepercayaan yang telah dipegang teguh secara turun temurun (Bermalang, 2016). Film horor Indonesia pada masa Orde Baru maupun pasca Orde Baru tidak jarang memunculkan unsur kegamaan atau religi. Salah satunya yaitu memunculkan peran tokoh agama dalam film.

Disini peneliti bertanya kepada informan bagaimana informan melihat tindakan yang dilakukan ustaz tersebut saat dimintai tolong Rini dan Tony untuk melihat rumahnya yang

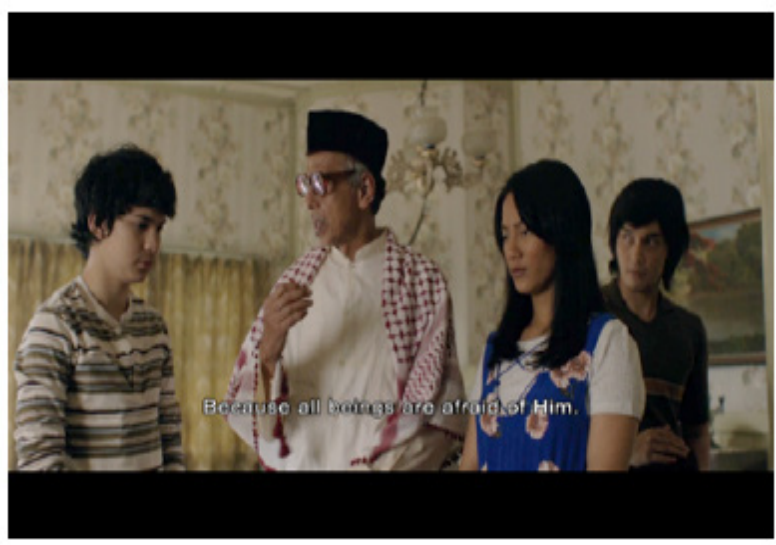

Sumber: Film Pengabdi Setan, 2017

\section{Gambar 2 Scene Ustad memberikan nasihat pada} Rini dan Tony di Film Pengabdi Setan

berhantu itu, meski ustaz tesebut terlihat hanya melihat-lihat dan menyuruh untuk sholat. Selain itu peneliti juga menanyakan mengenai seorang ustaz yang tergambarkan terbunuh oleh Ian adik Rini dan Tony yang dalam keadaan dirasuki oleh setan karena ia merupakan anak titisan setan. Kejadian atau penggambaran tokoh agama yang seperti ini jarang dimunculkan dalam film horor Indonesia, baru-baru ini saja hal seperti ini dimunculkan dan ada di film Pengabdi Setan (2017).

He'eh.. Tapi emang bener, benernya tuh ini sih.. ketika ada yang ganggu, ketika ada entah itu setan atau manusia benernya ya sholat, tingkatin ibadah. Gitu" (Mifta, Wawancara Personal, 2017).

Jadi ustaz ini kemudian menyarankan untuk sholat, karena sholat itu sebagai tameng salah satunya. Karena dengan sholat, harapannya keimanan seseorang akan meningkat" (Nanda, Wawancara Personal, 2019).

Berbeda dengan jawaban Mifta dan Nanda di atas, Dita sebagai informan 3 saat ditanyai apakah yang dilakukan ustaz dalam film ini 
sudah benar, ia mengatakan bahwa ustaznya terlihat powerless.

"Eee nek menurutku kurang sih, maksudnya nek misale aku seorang ustaz yang dimintai tolong kayak gini ya aku akan ngadain doa sesuai doa yang seperti di agama Islam sendiri ya kan. Mungkin shalawat itu tadi atau doa-doa tertentu, soalnya setauku ada sih di Islam sendiri ada doa khusus yang digunain kalo misalnya diganggu kan, tapi aku nggak tahu nama doanya apa. Disini pokoknya ustaznya digambarin powerless gitu kan ya?" (Dita, Wawancara Personal, 2019).

Disini Dita bahkan mengumpamakan dirinya sebagai ustaz, jika ia seorang ustaz maka doa khusus atau doa apapun yang memang sudah ada di ajaran Islam akan ia pakai untuk membantu keluarga Rini dalam film tersebut.

Berbeda dengan jawaban dari Topan sebagai informan 4, dimana dia menyetujui apabila yang dilakukan ustaz ini hanya terlihat menyuruh keluarga tersebut kembali sholat.

"Iya, soalnya ya sebenernya kalo katanya temen-temen.. lebih ini sih, sebagai ibadah yang untuk diri sendiri, tabungan, tapi juga sebagai perlindungan juga sehingga energienergi negatif itu nggak gampang deketin kita. Jadi lebih apa ya.. yang di absorb ke kita itu yang positif, jadi ini bener kalo nyuruh sholat gitu bukan mengusir. Soalnya tiap bangunan rumah itu sebenarnya memang perlu penjaga-penjaga kayak gitu, kalo nggak gitu ya apa ya.. bangunannya itu jadi nggak hidup".

Hampir sama dengan Topan, disini Dony sebagai informan 5 juga mengemukakan pendapatnya bahwa yang dilakukan ustaz ini adalah benar adanya.
Seperti tadi, pak ustaznya disitu kan juga udah bilang kalo dia cuma bisa berdoa sama Tuhan aja, terus juga nyuruh untuk mendekatkan diri ke Tuhan aja supaya ada perlindungan, pak ustaznya kan udah bilang gitu.. ya bener" (Doni, Wawancara Personal, 2019).

Maka dalam pengelompokan posisi jawaban, Dita memiliki jawaban paling berbeda dari informan lainnya, dimana ia termasuk dalam posisi dominant. Berada dalam posisi dominant dikarenakan ia tidak setuju dengan apa yang dilakukan ustaz tersebut, ia bahkan mengumpamakan dirinya sebagai ustaz tersebut jika ada seseorang yang meminta bantuan dalam hal-hal gaib. Baginya perlu dilakukan pembacaan doa-doa tertentu yang ada dalam agama Islam itu sendiri. Seperti halnya shalawat dan lain sebagainya, ia hanya menyebutkan doa-doa tertentu dan shalawat dikarenakan keterbatasan pengetahuannya mengenai ajaran Islam itu sendiri. Hal ini dipengaruhi oleh latar belakang agamanya sebagai orang Kristen, meski ia juga memiliki keluarga yang Muslim tetapi tetap saja pengetahuan tentang ajaran Islam terbatas. Selain itu ia juga sampai mampu memposisikan dirinya sebagai ustaz tersebut, dikarenakan hobinya yang suka menonton film Animasi, fantasi yang membuat ia imajinatif dan mampu membayangkan dirinya menjadi seorang ustaz yang ada dalam film itu.

Jawaban dari Mifta dan Nanda mengenai 
pembahasan ini termasuk dalam posisi negotiated. Dikarenakan Mifta dan Nanda merasa wajar bahwa ustaznya hanya melihatlihat, menyuruh sholat orang yang diganggu oleh setan. Seperti yang dikatakan Nanda pula, yang diperlukan adalah keimanan dan ketaqwaan seseorang kepada Tuhan-nya. Seperti halnya dalam Muhammadiyah sendiri, tidak seberapa memahami atau mendalami tentang hal-hal gaib seperti itu. Bagi mereka yang perlu dilakukan adalah yang sesuai logika saja, pola pikir mereka cenderung ke ilmiah. Hal itulah yang bisa membuat Nanda berpendapat bahwa ustaz dalam film ini seperti ustaz yang memang tidak paham mengenai hal gaib dan juga menurutnya sholat untuk tameng agar terhindar dari setan itu salah, yang benar keimanan dan ketaqwaan umat tersebut. Sedangkan Mifta mengatakan seperti itu karena memang latar belakang pendidikannya yang berbasis Islami dan kuliah jurusan bimbingan konseling Islam, ia jadi merasa memang perlu sholat untuk menjauhi hal-hal negatif seperti itu.

Kemudian untuk jawaban dari Topan dan Dony dalam pembahasan ini, jawaban keduanya termasuk dalam posisi oppositional. Dikarenakan Topan dan Dony disini setujusetuju saja dengan saran ustaz yang hanya menyuruh keluarga dalam film tersebut untuk beribadah kepada Tuhan. Dony disini hanya menjawab singkat bisa dikarenakan latar belakang agamanya yang Katolik dan tidak seberapa paham mengenai ajaran-ajaran di Islam pula. Sedangkan Topan menjawab seperti itu bisa dikarenakan ia sebagai pemeluk kepercayaan animisme atau Kejawen yang dimana pemikirannya cenderung mengarah ke logika atau realitas yang ada. Selain itu Topan juga menambahkan frame of reference-nya mengenai pentingnya sholat menurut temantemannya yang Muslim. Sehingga ia merasa bahwa memang benar ustaz tersebut menyuruh untuk beribadah atau sholat untuk mengusir hal-hal gaib atau negatif yang ada di rumah itu. Ia juga memiliki jawaban yang unik mengenai tidak perlu adanya pengusiran setan di rumah tersebut karena jika sebuah bangunan tidak ada unsur gaibnya dirasa ada yang kurang.

Tidak hanya tokoh agama Islam yang dihadirkan dalam film-film horor Indonesia, tetapi film ini menjadi film yang cukup berbeda

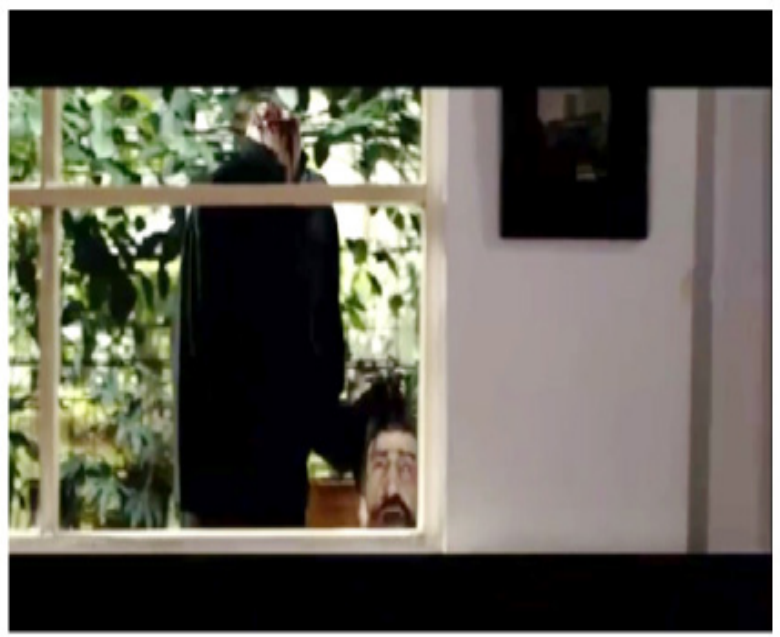

Sumber: Film Hantu Jeruk Purut Reborn, 2017

Gambar 3 Scene Setan Pastor Film Hantu Jeruk Purut Reborn 
dari yang lainnya. Dikarenakan cukup jarang dijumpai unsur-unsur religi dari agama Kristen, film ini berani beda dengan menghadirkan setan yang menyerupai seorang tokoh agama Kristen yaitu pendeta. Sosok pendeta ini memiliki makna orang yang dapat memberikan pengaruh kepada umat Kristen dan beberapa diantaranya menganggapnya seorang yang kudus.

Dita sebagai salah satu informan yang beragama Kristiani dan merupakan seorang guru SD sekaligus pelayan Tuhan di Gereja memiliki penerimaan mengenai topik ini, bahwa ia awalnya tidak memercayai bahwa setan itu adalah seorang pendeta atau pastor. Selain itu Dita juga menyadari dalam film tersebut bahwa sesungguhnya yang jadi setan itu bukanlah seorang pastor melainkan pemerkosa wanita yang menggunakan pakaian pastor. Disini Dita terlihat tidak setuju dengan pernyataan mengenai pastor yang gentayangan menjadi setan, namun jika memang dalam film tersebut setannya benar seorang pastor, iya memiliki rasa percaya. Seperti yang dikatakannya:

Hmm, kalau beneran aku percaya sih. Maksudnya, ya.. namanya pendeta juga manusia gitu kan? Memang kalau apalagi dia dibunuh dengan cara yang nggak wajar, bisa aja dia gentayangan hehe" (Dita, Wawancara Personal, 2019).

Sedangkan Nanda memiliki pendapat bahwa setan tersebut bukanlah seorang pastor, melainkan setan atau jin yang menyamar menjadi pastor.

Tokoh agama maksudnya? Sekali lagi, kan yang menggentayangi kan bukan pastornya, atau bukan tokoh agama tersebut. Kan yang jelas itu setan ataupun jin yang menyerupai pastor seperti itu, kan yang disini sebenarnya yang dibunuh bukan pastor.. tapi orang lain yang kemudian berpura-pura menjadi pastor, seperti itu. Dan saya rasa untuk menjadi seperti itu setan mudah saja.." (Nanda, Wawancara Personal, 2019).

Kemudian Dony disini juga berpendapat yang sama dengan Nanda bahwa bisa saja itu adalah setan yang menyamar menjadi pastor. Namun ia juga mengatakan bahwa bisa juga itu adalah pastor yang meninggal tidak tenang, sehingga rohnya masih melayang mencari tempat.

Berbeda dengan ketiga informan di atas, Mifta dan Topan hampir memiliki jawaban yang sama. Bedanya Mifta memiliki penerimaan bahwa penggambaran pastor sebagai setan di film ini adalah tidak etis.

Ya kurang menghargai nggak sih.. soalnya kayak misalnya aku pun, kyai masa iya dijadiin setan.. kan pasti umat Muslim nya kayak "Ih kurang ajar banget sih.." gitu ya.. pasti agama apapun, iya nggak sih? Apalagi itu kan tokoh yang mengajarkan agama, masa iya orang yang mengajari agama itu dijadiin yang sosok hantu.. kurang etis aja sih" (Mita, Wawancara Personal, 2019).

Sedangkan yang dikatakan Topan memang hampir sama dengan jawaban Mifta, bedanya disini Topan memiliki penerimaan bahwa seorang tokoh agama pasti akan senang-senang 
saja jika meninggal, sehingga baginya tidak

akan ada tokoh agama yang menjadi setan.

"Nggak sih, ini ngawur sih ini kalo aku bilang.. karena menurutku ini ya nggak mungkin juga ee apa ya? Tokoh-tokoh agama itu pastinya mereka.. ee ini, bedanya mereka dengan orang-orang biasa itu mereka ajal itu malah seneng. Kenapa? Dunia ini complicated, kalo di akhirat itu.. ee apa ya? Kedua hal baik dan buruk ini dipisah, nah kalo di dunia ini.. disaat kita.. ee kalo kehilangan orang yang kita sayang itu mungkin bakal sedih, senang dan sedih itu bersamaan. Bukan senang setelah sedih atau sedih setelah senang, bukan.. tapi bersamaan. Nah, kalo misalkan tokoh agama ini ajal dia senang.. ya wes gapopo, aku mau tersiksa atau mungkin ee bahagia kalo di surga.. ee karena nggak ada complicated. Ee kalo sendiri ya gak mau melbu surga hehe.. karena terlalu tidak ada.. ee apa ya? Santai hehe. Biasanya kan kalo gentayangan itu karena mungkin mereka belum ikhlas meninggal gitu ya, nah kalo menurutku tokoh agama dijadiin setan kayak gini, ya nggak masuk akal.. mereka pasti ikhlas kalo meninggal, meskipun dibunuh pun itu lho nggak mungkin. Dia pasti seneng, paling kalo sakit ya udah gak usah dibawa ke rumah sakit.. ngono wes ta haha. Ya menurutku ini agak ada pelecehannya ya, apalagi ini tokoh agama ya yang dijadikan setan.. kalo yang dijadikan setan ini dukun gitu ya gapapa. Soalnya kalo dukun itu kan pasti masih ada dendam gitu, kecuali kalo pastor, biksu, romo, kyai, itu menurutku mereka kalo ajal ya bakal seneng" (Topan, Wawancara Personal, 2019).

Dari jawaban Nanda, Dita, dan Dony di atas, mereka tergolong pada posisi oppositional yang dimana Dita menolak bahwa setan dalam film ini adalah seorang pastor. Selain itu juga ia juga memiliki pemikiran bahwa seorang pastor tidaklah bisa diandalkan sepenuhnya, bahkan kudus atau suci sepenuhnya karena ia menganggap pastor adalah sama dengan kita semua seorang manusia biasa. Sedangkan Mifta dan Topan memiliki penerimaan yang dapat dikategorikan ke dalam posisi dominant. Dikarenakan Mifta disini berpendapat bahwa tokoh agama yang digambarkan menjadi setan ini dianggapnya kurang menghargai atau kurang etis. Hal ini dipengaruhi oleh latar belakang Mifta yang berpendidikan sarjana Bimbingan Konseling Islam yang pasti membuatnya merasa tokoh agama itu perlu dihormati.

Ritual keagamaan yang pertama akan dibahas yaitu adanya orang yang kerasukan saat sedang beribadah atau sholat dalam film Asih (2018). Dimana Puspita sebagai ibu yang baru saja melahirkan seorang anak, ia mengalami gangguan dari setan Asih yang telah mengincar anaknya untuk dibawa pergi. Saat-saat terakhir

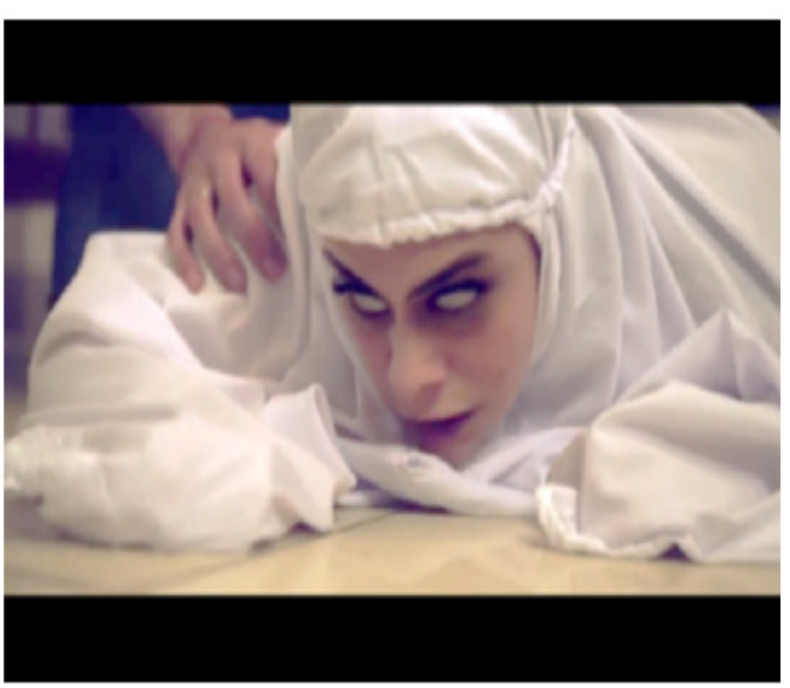

Sumber: Film Asih, 2018

Gambar 4 Scene Puspita kerasukan setan Asih 
dimana anak Puspita telah kembali ke pelukan Puspita dan keluarga yang sebelumnya anak tersebut sempat terambil oleh Asih. Puspita yang awalnya sedang dzikir, tiba-tiba terasuki oleh setan Asih.

Dalam film Ruqyah: The Exorcism (2017) ini terdapat scene yang menggambarkan orang sholat bersama. Disini Mahisa berusaha mengajak seorang wanita yang mempunyai latar belakang memakai susuk atau pegangan dalam dirinya. Wanita ini berusaha ingin melepas tubuhnya dari belenggu susuk yang menyiksa tersebut, akhirnya ia menyetujui untuk sholat bersama dengan Mahisa. Namun di tengahtengah ibadah sholat, wanita ini kerasukan. Ibadah sholat itu sendiri seharusnya menjadi gambaran yang baik, dan dalam keadaan yang bersih atau suci karena saat itulah umat manusia berbicara dengan Tuhan-nya. Namun di film ini

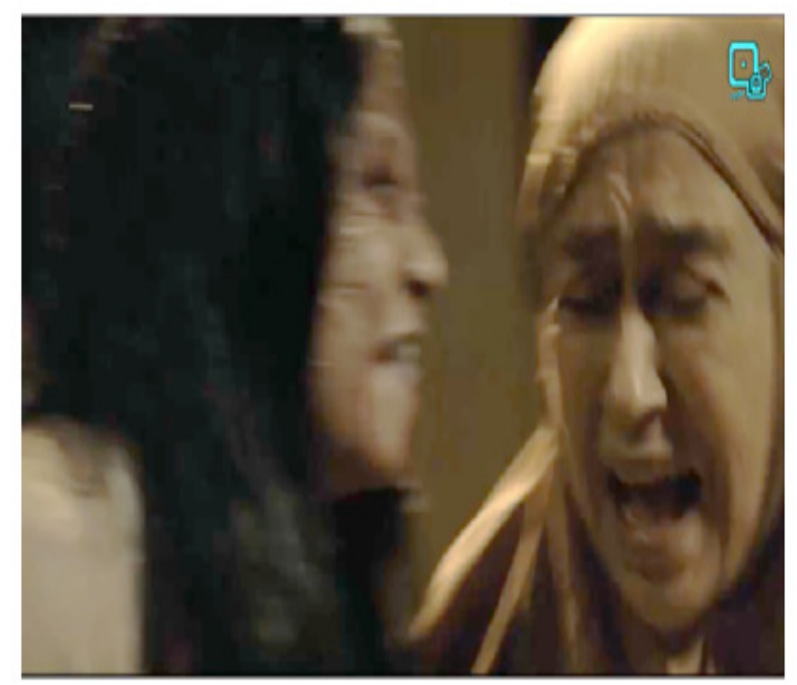

Sumber: Film Ruqyah: The Exorcism, 2017

Gambar 5 Scene kerasukan setan saat sholat digambarkan berbeda atau bahkan negatif, maka peneliti ingin menanyakan kepada informan apakah hal ini wajar untuk terjadi.

Dalam film Asih (2018) terdapat scene ibu dari suami Puspita berdzikir setelah sholat. Namun saat berdzikir, ia diganggu oleh keberadaan setan Asih tersebut yang berjalan dan bersenandung. Sampai pada akhirnya nenek tersebut terkejut dengan adanya Asih yang tiba-tiba muncul di sampingnya dan berteriak. Dari sini dapat dilihat hal yang bisa dibilang janggal, karena orang yang sedang terlihat khusyuk berdoa pada akhirnya terganggu oleh kehadiran setan. Penerimaan tiap orang tentu berbeda, disini peneliti menanyakan bagaimana penerimaan informan mengenai hal seperti ini. Sudah jelas film horor akhir-akhir ini banyak memunculkan unsur keagamaan namun dimunculkan dengan cara yang seperti ini.

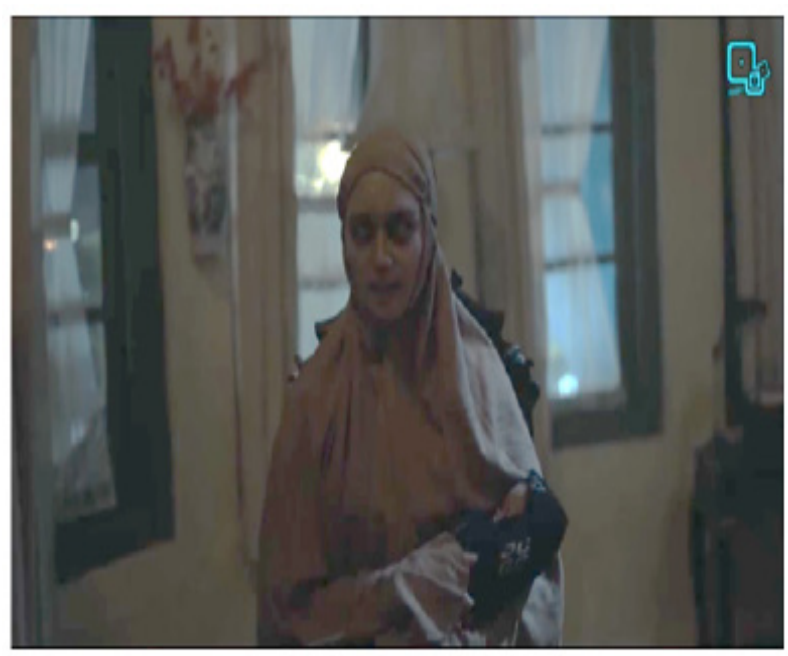

Sumber: Film Asih, 2018

Gambar 6 Scene orang yang diganggu setan saat dzikir 


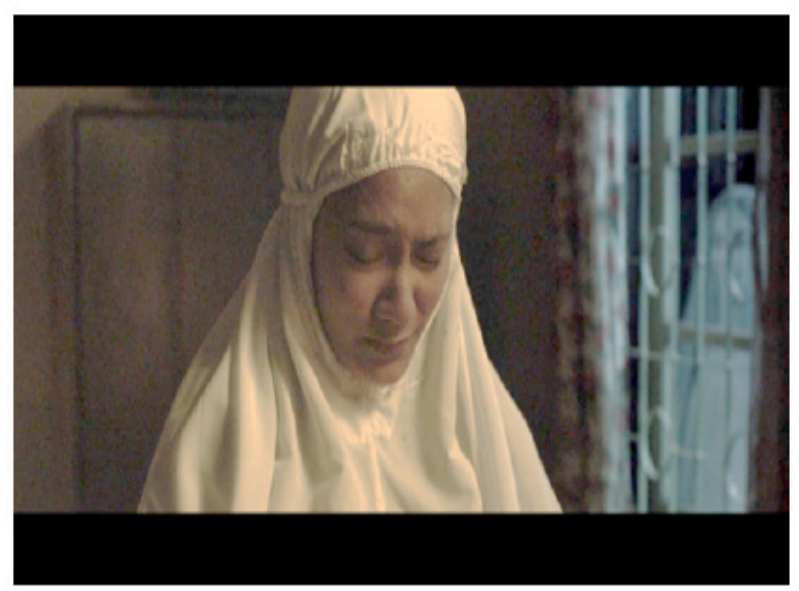

Sumber: Film Danur 2: Maddah, 2018

Gambar 7 Scene orang yang diganggu setan saat sholat

Selanjutnya, dalam film Danur 2: Maddah (2018) ada scene dimana saat tante Tina sedang menjalankan ibadah sholat yang kemudian muncul setan di sekitar tante Tina. Disini peneliti menanyakan bagaimana pendapat informan mengenai kejadian seperti ini, apakah wajar terjadi atau tidak. Karena menurut peneliti sendiri, seharusnya saat beribadah kita bisa terjauhkan atau terhindar dari hal-hal yang negatif. Pada scene ini Mifta sebagai informan 1 menyampaikan bahwa memang ada yang janggal, Mifta menyampaikan pendapatnya itu dengan menirukan gerakan sholat tante Tina yang ada di film (posisi sholat duduk bersimpuh dan menggoyangkan badan ke kanan dan kiri pelan-pelan).

Setelah itu, dalam film Pengabdi Setan (2017) terdapat scene dimana setan ibu dari Rini dan adik-adiknya menghantui di rumah mereka. Salah satunya yaitu saat Rini menjalankan

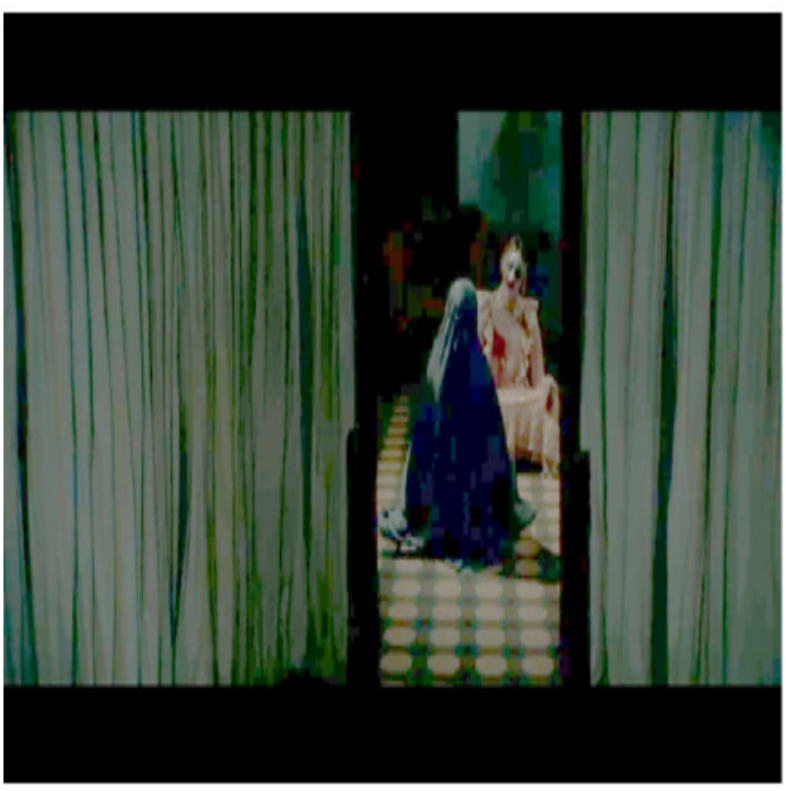

Sumber: Film Pengabdi Setan, 2017

\section{Gambar 8 Scene Rini terganggu oleh setan saat sholat}

sholat seperti nasihat dari ustaz yang diundang ke rumahnya untuk melihat keadaan rumahnya yang berhantu dan penuh gangguan itu. Selama menjalankan ibadah sholat, Rini mengalami kegelisahan atau ketakutan karena ia merasa ada sosok yang melihatnya atau mendekati dirinya. Tak lama setelah ia usai menjalankan ibadah sholat, ia diganggu oleh setan ibunya. Hal seperti ini jarang tergambarkan atau terjadi dalam film-film horor Indonesia tahun-tahun sebelumnya. Maka dari itu peneliti menanyakan hal ini kepada informan, apakah hal seperti ini bisa dibilang wajar atau tidak, masuk akal atau tidak, padahal Rini sudah berusaha untuk sholat sesuai dengan nasihat dari ustaz.

\section{Selanjutnya film Hantu Rumah Ampera} (2009). Film ini menceritakan keluarga yang menempati ke rumah yang baru. Di rumah 


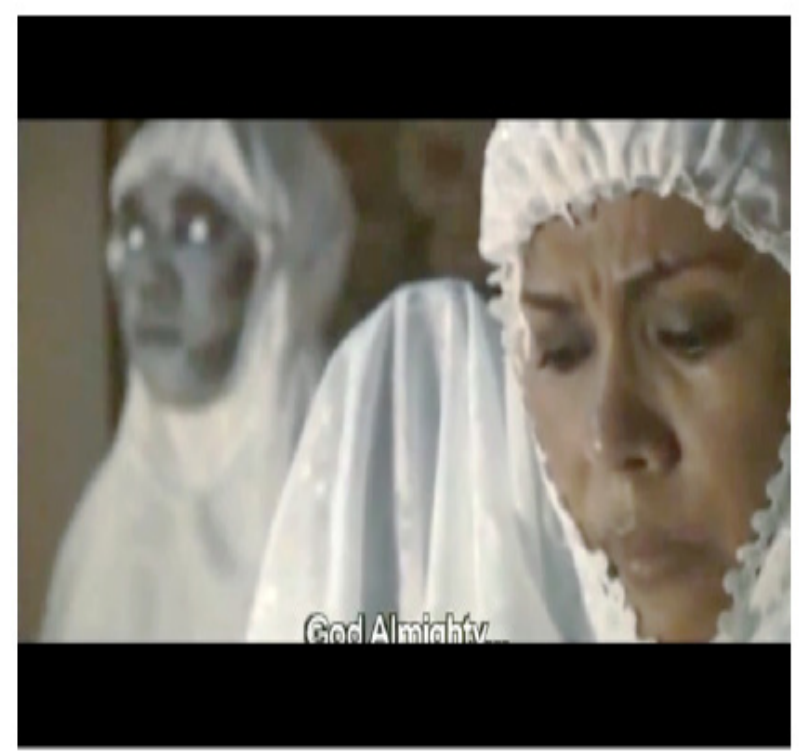

Sumber: Film Hantu Rumah Ampera, 2009

Gambar 9 Scene ibu Adit diganggu setan saat sholat

baru tersebut banyak kejadian aneh yang mengganggu mereka. Salah satunya, adanya setan yang memakai mukena dan kemudian ikut sholat. Gerakan, doa, semuanya diikuti dan sama persis dengan yang dilakukan ibu Adit. Disini peneliti menanyakan kepada informan bagaimana pendapat mereka mengenai hal ini, apakah wajar saja terjadi bagi mereka. Mengingat kembali, ini adalah sebuah ritual agama, beribadah, sholat kepada Tuhan.

Dalam film Asih (2018) terdapat scene nenek atau ibu dari suami Puspita sedang berwudhu. Disini nenek tersebut terlihat dengan khusyuk dan sungguh-sungguh dalam wudhunya, namun tiba-tiba ia mulai mendengar ada suara wanita yang bersenandung dan berjalan menuju lorong dekat kamar mandi tersebut. Setan Asih lah yang berjalan di lorong rumah sambil bersenandung, seketika nenek tersebut sempat berhenti dan memastikan apa yang dirasakan itu benar bahwa ada orang yang sedang lewat. Disini peneliti menanyakan kepada informan bagaimana penerimaan mereka mengenai orang yang diganggu saat wudhu, dan menanyakan apakah berwudhu itu merupakan ritual keagamaan yang bisa dibilang sakral.

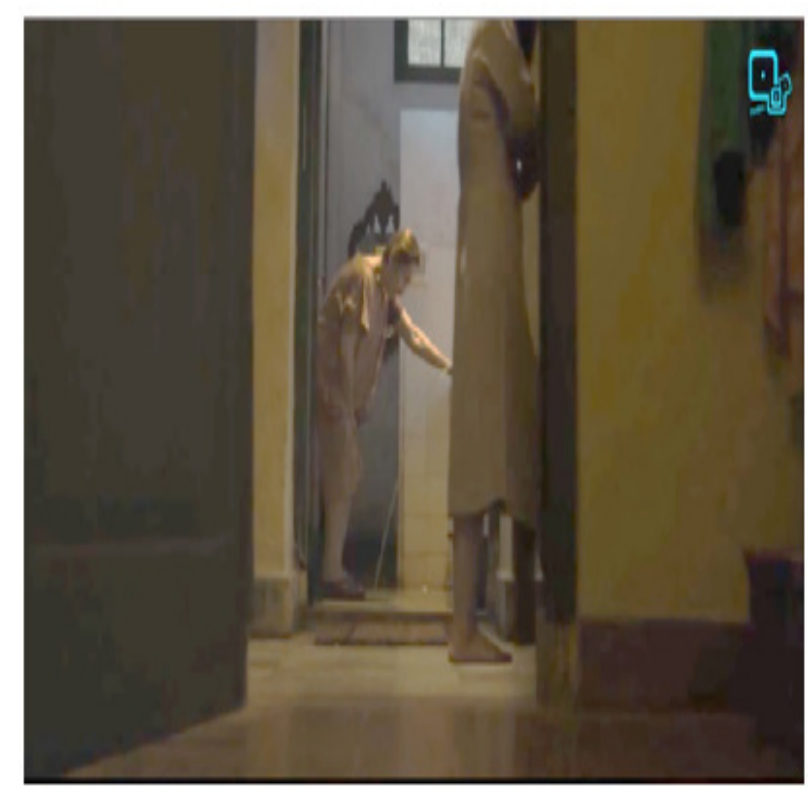

Sumber: Film Asih, 2018

\section{Gambar 10 Scene ibu wudhu dan terganggu Asih yang berjalan}

Selanjutnya, sama dengan film Asih (2018) kejadian serupa terjadi di dalam film Pengabdi Setan (2017). Saat Rini melakukan wudhu, ia merasa was-was dan ketakutan karena sempat melihat sosok setan yang menyerupai ibunya di dekat tempat ia berwudhu.

Selain diganggu saat wudhu, ada pula scene dalam salah satu film horor Indonesia pasca Orde Baru tepatnya tahun 2018 yaitu Danur 2: Maddah, yang memunculkan scene 

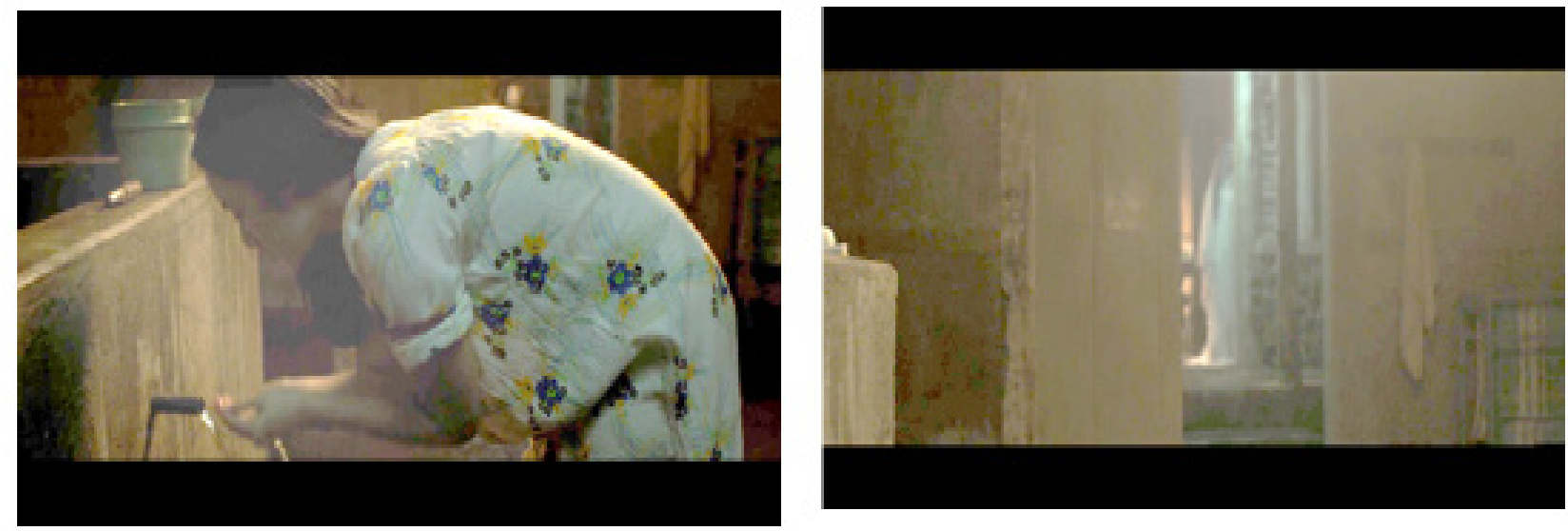

Sumber: Film Pengabdi Setan, 2017

Gambar 11 Scene Rini yang terganggu setan ibu saat wudhu
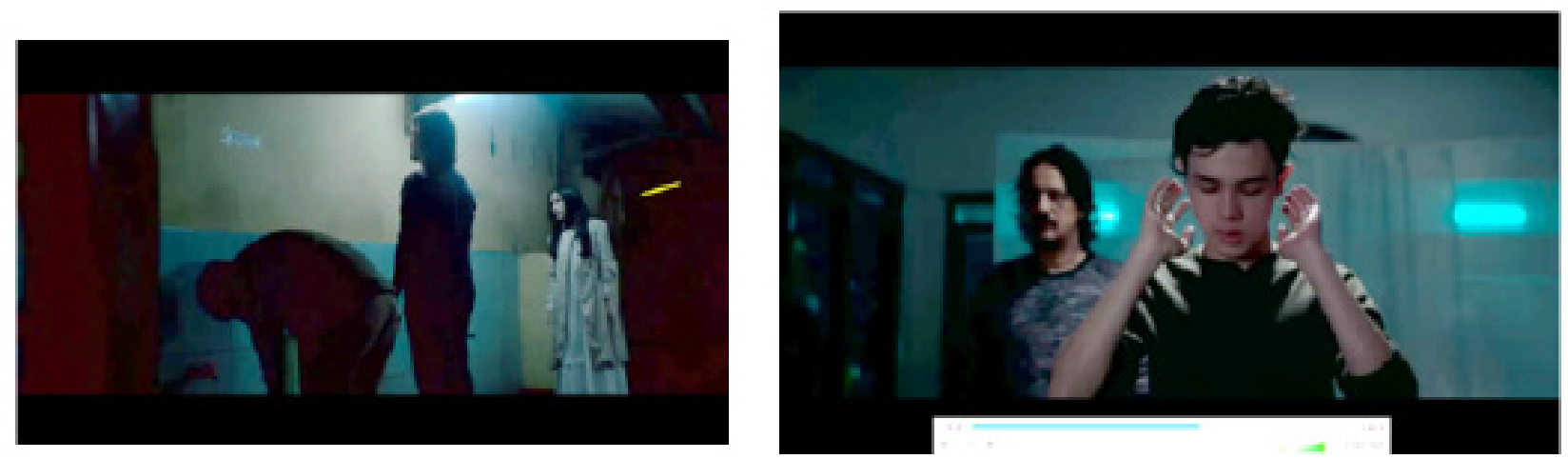

Sumber: Film Danur 2: Maddah, 2018

Gambar 12 Scene om Ahmad memasuki Masjid tanpa berwudhu

Angki sepupu Risa yang sedang wudhu dan mengajak ayahnya juga om Ahmad, namun ia tidak wudhu.

Dari sini dapat terlihat dengan jelas, seharusnya atau biasanya orang yang hendak ibadah sholat akan wudhu terlebih dahulu. Dan disini Angki tetap mengajak sholat subuh ayahnya di Masjid Rumah Sakit. Tanpa wudhu terlebih dahulu. Hal ini memunculkan pertanyaan apakah hal tersebut benar untuk dilakukan atau tidak. Mifta setelah melihat scene ini ia tersadar bahwa ayahnya itu dalam keadaan dirasuki setan dan diajak wudhu lalu masuk Masjid untuk sholat tanpa ada penolakan sama sekali.

Dalam film Asih (2018) ini sungguh berbeda dari film-film horor Indonesia lainnya. Disini tasbih terlihat terputus saat dipakai berdzikir saat sebelum orang tersebut terasuki setan.

Informan 1, Mifta memiliki pendapat bahwa hal ini wajar saja karena tasbih itu sendiri baginya hanyalah alat bantu. Begitupun dengan Nanda, ia tidak memiliki pendapat atau penerimaan khusus mengenai tasbih yang 


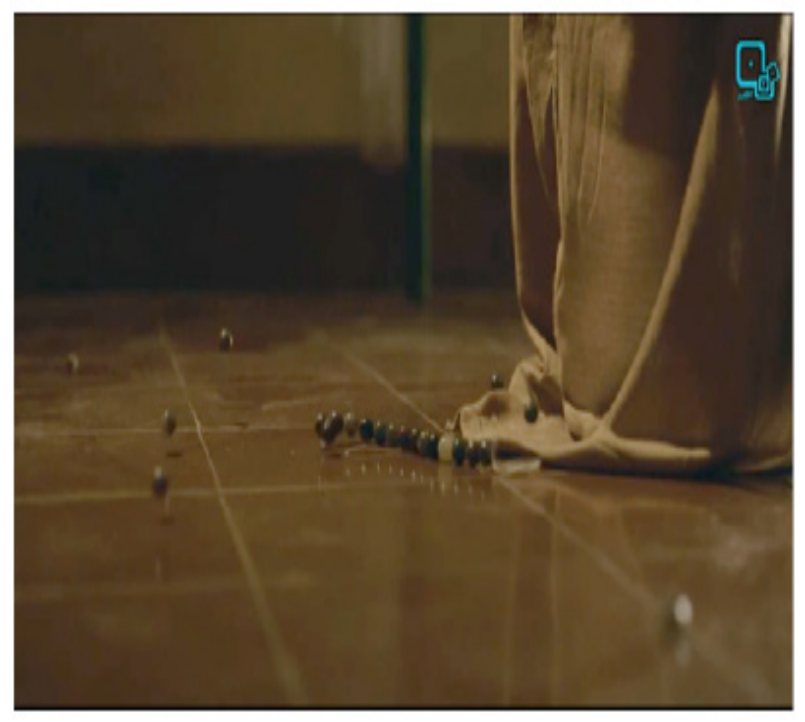

Sumber: Film Asih, 2018

\section{Gambar 13 Scene tasbih yang terputus saat berdzikir}

terputus ini. Baginya hanya karena kuatnya energi dari setan yang masuk itu sendiri.

"Ya.. itu terlalu kuatnya setan masuk ke dalam tubuhnya itu bisa untuk kemudian tasbihnya putus gitu. Kalo orang biasanya orang Jawa tuh burung gagak itu.. " (Nanda, wawancara personal 2019).

Dita juga mengakui bahwa dirinya tidak mengetahui apapun mengenai arti dari tasbih yang terputus tersebut.

"Aku sebenernya nggak ngerti sih.. makna tasbih terputus disini apa. Cuma pas aku lihat, pas adegan setelah ini kan.. pas tasbih terputus itu kan dia kerasukan ya? Nah, mungkin.. mungkin ya? Maksudnya saat tasbih terputus itu tuh semacem kayak imannya dia tuh kayak bukan terputus sih, tapi imannya kayak tergoyahkan akhirnya si hantu ini bisa masuk ke dirinya. Mungkin interpretasi dari itu ya.. "(Dita, wawancara personal 2019).

"Ya baru ini sih lihat wiritan, tasbih terputus. Tapi mungkin ini juga dia berdoa kan, bermunajat.. bermunajat itu memohon. Ini dia minta sama Tuhan, ya mungkin ini isyarat dari Tuhan kalo sudah.. usahamu sudah tercapai, sudah ada hasil.. nah itu dikasih tandanya lewat tasbihnya yang terputus itu, munajatnya sudah tercapai“" (Topan, wawancara personal 2019).

Maka dalam pembahasan tasbih yang terputus ini dapat dilihat bahwa pendapat atau penerimaan dari Mifta, Nanda, dan Dony digolongkan dalam posisi oppositional. Dikarenakan jawaban Mifta yang hanya menganggap tasbih tak lebih dari sebuah benda saja, disini ia bisa menganggap seperti itu karena tidak meyakini ada simbol atau benda keagamaan yang sakral atau yang perlu dihormati dalam Islam kecuali Al-Quran. Sedangkan Nanda menganggap itu wajar karena kekuatan setan yang masuk dalam tubuh orang tersebut, ia membahas mengenai kekuatan setan yang masuk. Hal ini bisa dipengaruhi oleh pola pikirnya sebagai orang Muhammadiyah yang lebih scientific atau berintelektual jika menghadapi hal-hal seperti ini. Begitu pula dengan Dony yang menganggap hal tersebut hanya untuk mendramatisir filmnya saja. Jawabannya disini dipengaruhi oleh latar belakangnya yang cenderung berpola pikir realistis, mungkin hal ini disebabkan oleh pendidikannya dahulu mengenai teknik. Dimana orang teknik lebih belajar ke ilmu yang sudah pasti sehingga pola pikirnya untuk bernalar sedikit.

Di sisi lain, jawaban dari Dita dan Topan dapat digolongkan ke dalam posisi negotiated. 
Dita tidak mengetahui arti sebenarnya dari tasbih yang terputus tersebut dikarenakan dibatasi oleh latar belakang agamanya yang Kristen. Topan juga belum pernah melihat tasbih saat wiridan terputus, selain itu ia juga berpikiran mungkin itu adalah tanda dari Tuhan mengenai permohonan orang tersebut bahwa permohonannya telah selesai dikabulkan. Pemikirannya ini dipengaruhi oleh cerita film yang sebelumnya memang digambarkan orang tersebut bersedih dan ingin anaknya kembali pulang. Dari situ Topan berpikiran bahwa mungkin saja itu adalah munajat atau permohonan yang dianggap sudah selesai. Selain itu pemikirannya mengenai munajat (berdoa sepenuh hati kepada Tuhan) ini bisa jadi berasal dari latar belakang kepercayaannya yang memang sering kali bersemedi, bertapa, maupun berpuasa dengan suatu tujuan
(Endraswara, 2018).

Dari keseluruhan penerimaan informan dalam topik pembahasan ini, sebagian besar informan cenderung berada pada posisi oppositional. Ini diartikan sebagian besar informan menolak akan adanya fenomena desakralisasi mengenai tokoh, ritual, hingga benda maupun simbol keagamaan dalam film pilihan peneliti.

Dari tabel 1, posisi penerimaan informan dan penjelasan tiap penerimaan informan di atas dapat terlihat bahwa informan sebagai penonton aktif telah berhasil menafsirkan pesan yang disampaikan media film berdasarkan latar belakang masing-masing. Selain itu dari tabel 1 dapat dilihat sebagian besar informan menolak menerima adanya desakralisasi dalam film horor Indonesia terutama mengenai tokoh dan benda atau simbol keagamaan, bisa dikatakan sebagian

Tabel 1 Posisi Penerimaan Informan mengenai Desakralisasi Tokoh, Ritual, dan Benda Keagamaan dalam Film Horor Indonesia Pasca Orde Baru

\begin{tabular}{|c|c|c|c|}
\hline \multirow[b]{2}{*}{ INFORMAN } & \multicolumn{3}{|c|}{ TOPIK PEMBAHASAN } \\
\hline & Tokoh Agama & Ritual Keagamaan & $\begin{array}{c}\text { Benda atau Simbol } \\
\text { Keagamaan }\end{array}$ \\
\hline $\begin{array}{l}\text { Informan } 1 \\
\text { (Islam organisasi } \\
\text { Nahdlatul Ulama) }\end{array}$ & Negotiated & Negotiated & Oppositional \\
\hline $\begin{array}{l}\text { Informan } 2 \\
\text { (Islam organisasi } \\
\text { Muhammadiyah) }\end{array}$ & Negotiated & Oppositional & Oppositional \\
\hline $\begin{array}{l}\text { Informan } 3 \\
\text { (Kristen) }\end{array}$ & Negotiated & Oppositional & Negotiated \\
\hline $\begin{array}{l}\text { Informan } 4 \\
\text { (Kejawen) }\end{array}$ & Negotiated & Negotiated & Negotiated \\
\hline $\begin{array}{l}\text { Informan } 5 \\
\text { (Katolik) }\end{array}$ & Oppositional & Oppositional & Oppositional \\
\hline
\end{tabular}

Sumber: Olahan Peneliti, 2019 
besar ada pada posisi oppositional. Sesuai dengan rumusan masalah pada penelitian ini, dalam hasil temuan data peneliti tidak ditemukan informan dengan posisi yang dominant. Namun di sisi lain penelitian ini cukup memberikan hasil bervariasi mengenai penerimaan tiap informan dengan latar belakang yang berbeda-beda untuk menafsirkan suatu pesan dalam media film. Hasil penerimaan informan yang bervariasi dan memaknai pesan dalam media film sesuai dengan latar belakang masing-masing, telah sesuai dengan apa yang dikatakan oleh McQuail (1997), bahwa penonton disebut sebagai interpretive communitive. penonton selalu aktif dalam mempersepsi pesan dan memproduksi makna, tidak hanya sekedar menjadi individu pasif yang hanya menerima saja makna yang diproduksi media massa. Artinya, penonton bukanlah individu yang pasif.

\section{SIMPULAN}

Penelitian dengan metode reception analysis ini membahas bagaimana penonton menerima desakralisasi tentang tokoh dan simbol agama dalam film horor Indonesia pasca Orde Baru. Informan dengan karakteristik yang telah ditentukan peneliti disini menjadi penonton aktif yang menafsirkan sebuah pesan yang ada pada media film. Setelah menonton dan menyampaikan tafsiran yang diterima penonton, peneliti melakukan kategorisasi terhadap penerimaan tersebut. Kategorisasi ini ada tiga jenis, yaitu: dominant, negotiated, dan oppositional. Dalam pembahasan yang pertama mengenai desakralisasi tokoh agama, disini hanya informan dengan latar belakang agama Katolik saja yang memiliki posisi oppositional, lainnya merupakan negotiated. Dari sini bisa terlihat bahwa penonton atau informan menyadari, setuju, atau menganggap tidak wajar terhadap apa yang film tampilkan mengenai tokoh agama tersebut. Namun disisi lain penonton atau informan masih ragu akan beberapa hal, seperti ustaz yang dianggap yang tidak paham akan hal gaib, atau mengenai tidak etisnya melihat seorang pastor menjadi setan, dan sebagainya. Munculnya penerimaan seperti itu juga dipengaruhi bagaimana dalam kehidupan sehari hari informan berpandangan mengenai tokoh agama.

Pembahasan kedua membahas desakralisasi mengenai ritual keagamaan. Sebagian besar penonton atau informan berada dalam posisi oppositional. Informan yang dengan jelas menolak akan adanya desakralisasi mengenai ritual keagamaan dalam film pilihan peneliti ialah informan dengan latar belakang agama Islam dengan organisasi Muhammadiyah, agama Kristen, dan agama Katolik. Sedangkan informan dengan latar belakang Islam dengan organisasi Nahdlatul Ulama dan kepercayaan Kejawen lebih mengarah kepada ragu-ragu 
untuk setuju dan tidak setuju. Informan cenderung pada posisi oppositional karena dipengaruhi oleh field of experience terhadap sebuah ritual-ritual. Ada yang pernah melewati ritual pembukaan mata batin, melakukan ritual atau ibadah kemudian mengalami hal yang sama seperti dalam film, dan lain sebagainya. Kebanyakan informan lebih mengedepankan pengalaman sehingga apa yang ada dalam film tidak sesuai karena tidak sesuai seperti yang pernah dialami.

Pada pembahasan yang terakhir, membahas tentang desakralisasi mengenai benda atau simbol keagamaan. Dalam pembahasan ini penonton atau informan lebih cenderung berada di posisi oppositional. Disini sebagian besar informan menolak akan adanya desakralisasi benda atau simbol keagamaan dalam film, yaitu informan yang berlatar belakang agama Islam (Nahdlatul Ulama dan Muhammadiyah), serta informan yang beragama Katolik. Disisi lain informan dengan latar belakang agama Kristen Protestan dan kepercayaan Kejawen ragu untuk menerima adanya desakralisasi atau tidak. Sebagian besar informan atau penonton pada dasarnya tidak memiliki ikatan atau makna penting mengenai tasbih itu sendiri, kebanyakan menganggap tasbih hanya alat bantu doa saja. Durkheim menyatakan bahwa suci atau sakral bukan merupakan sifat dari benda atau hal itu sendiri namun diberikan oleh masyarakat yang menyucikannya (Agus, 2006). masyarakat yang mempercayainya sajalah yang membuat sesuatu menjadi suci atau bertuah.

Maka, bisa ditarik secara garis besar bahwa posisi penerimaan penonton mengenai topik penelitian ini adalah oppositional. Penonton tidak memiliki reaksi apapun terhadap adanya pesan desakralisasi dalam film horor Indonesia pasca Orde Baru. Penerimaan yang cenderung oppositional ini bisa saja dipengaruhi oleh pribadi masing-masing yang cenderung menjalankan agama dalam kehidupan dengan cukup baik dan memiliki field of experience yang berbanding terbalik dengan yang ada dalam film. Selain itu penonton juga cenderung mengedepankan realita yang ada atau pikiran yang rasional. Sehingga penonton atau informan terlena dengan munculnya sisi baik atau religi dalam film horor Indonesia, karena pada awal pasca Orde Baru masyarakat Indonesia disajikan dengan film horor Indonesia yang masih mengandung adegan dewasa atau komedi yang dirasa tidak sesuai dengan film horor.

Saran penelitian selanjutnya dapat dilakukan dengan metode semiotik, bagaimana film-film Indonesia mendesakralisasi pemuka agama di Indonesia.

\section{DAFTAR PUSTAKA}

Agus, B. (2006). Agama dalam kehidupan manusia: pengantar antropologi agama. 
Jakarta: Raja Grafindo Persada.

Bermalang, J. C. (2016). Komunikasi antar pribadi tokoh agama tentang bahaya minuman keras kepada remaja di Kelurahan Maksubun Kabupaten Sorong, e-Jurnal “Acta Diurna”. 5, 5.

Endraswara, S. (2018). Mistik Kejawen (sinkretisme, simbolisme dan sufisme dalam budaya spiritual Jawa). Yogyakarta: Narasi.

Hadi, S. T. (2006). Seni alam ritual agama. Yogyakarta: Pustaka.

Hall, S. (2005). Culture, media, languange. New York: Taylor \& Francis e-Library.

Heeren, K. v. (2012). Contemporary Indonesian film (spirits of reform and ghosts from the past). Leiden: Brill.

Heeren, K. v. (2007). Return of the kyai: representations of horror, commerce, and censorship in post-Suharto Indonesian film and television, Inter-Asia cultural studies. $8,2$.

Herawati, E. (2011). Pornografi dalam balutan film bertema horor mistik di Indonesia, HUMANIORA. 2, 2.

Imran, H. A. (2012). Media Massa, Khalayak Media, The Audience Theory, Efek Isi Media dan Fenomena Diskursif (Sebuah Tinjauan dengan Kasus pada Surat Kabar Rakyat Merdeka). Jurnal Studi Komunikasi dan Media. 16, 1.

Lapian, A. H. (2017). Representasi desakralisasi tokoh agama Katolik dalam film "Vatican Tapes”, Jurnal e-Komunikasi. 5, 1.

Lutfi, M.\& Trilaksana,A.(2013). Perkembangan film horor Indonesia tahun 1981-1991, AVATARA. 1, 1.

McQuail, D. (1997). Audience analysis. SAGE Publications.

Muhammad, N. (2013). Memahami konsep sakral dan profan dalam agama-agama, Jurnal Substantia. 15, 2.

Sukatno, D. \& Bazaleel, M. (2014). Analisis film horor Indonesia produksi tahun 2014 (studi kasus: Mall Klender dan Kamar 207), Andharupa. 2, 1. 